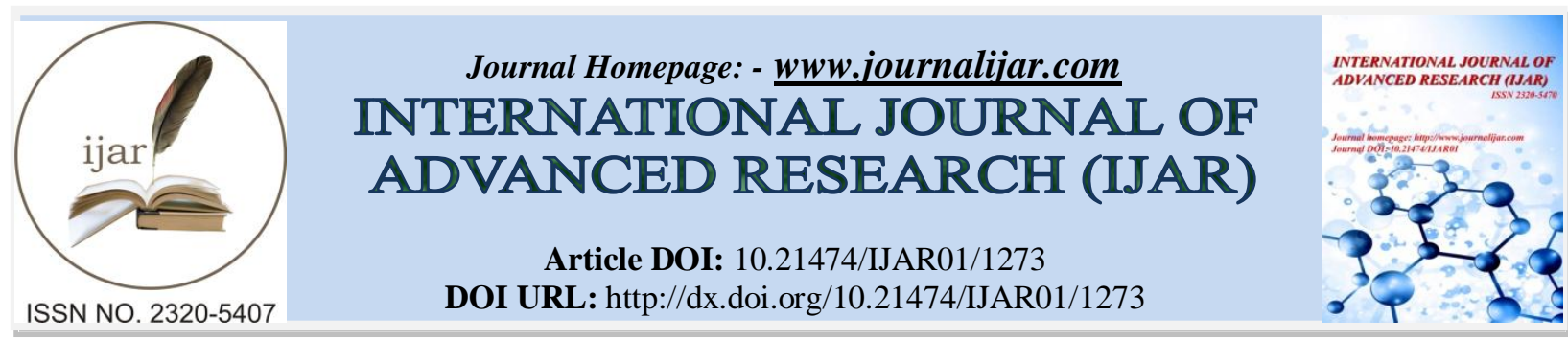

RESEARCH ARTICLE

\title{
EFFECT OF SUPPLEMENTING TWO DIFFERENT COMMERCIAL STRAINS OF YEAST CULTURES ON RUMEN FERMENTATION, NUTRIENT DIGESTIBILITY AND BIO-CHEMICAL PROFILE IN KANKREJ COWS.
}

\author{
B M Bhanderi ${ }^{\text {** }}$, Subhash Parnerkar ${ }^{2}$, Ashish Aggarwal ${ }^{2}$, Sachin Shankhpal ${ }^{2}$, Harshala Thube ${ }^{2}$ and S \\ Pathan $^{2}$. \\ 1. Animal Nutrition Group, National Dairy Development Board, Anand-388001, Gujarat, India. \\ 2. Animal Nutrition Research Department, College of Veterinary Science and Animal Husbandry, Anand \\ Agricultural University, Anand-388001, Gujarat, India.
}

\section{Manuscript Info}

Manuscript History

Received: 12 June 2016

Final Accepted: 18 July 2016

Published: August 2016

Key words:-

Kankrej cows, nutrient digestibility, rumen fermentation, total mixed ration, yeast culture

\section{Abstract}

The present study was conducted to test efficacy of supplementing two commercial probiotics (Saccharomyces cerevisiae) Yea-Sacc ${ }^{1026}$ (YC-1) of M/s. Alltech and Levucell SC-20 strain: CNCM I-1077 (YC-2) of $\mathrm{M} / \mathrm{s}$. Lallemand Animal Nutrition on the rumen fermentation, nutrient digestibility and bio-chemical profile in Kankrej animals. Based on the in vitro studies, optimum levels for incorporation of live yeast strains YC-1 and YC-2 in 50:50 concentrates: wheat straw based total mixed ration (TMR) were found to be 15 and $1.5 \mathrm{~g} /$ day, respectively. Fifteen animals were selected and divided into three equal groups of 5 in each, based on the body weight and age for allocating dietary treatments. The animals in group $\mathrm{T}_{0}$ (control group) were fed 50:50 concentrates: wheat straw based TMR without yeast culture, to meet nutrient needs as per NRC (2001) standard, whereas, animals under $\mathrm{T}_{1}$ and $\mathrm{T}_{2}$ groups were fed TMR containing YC-1 and YC-2 @ 15 and 1.5 g/animal/day, respectively. After 40 days of experimental feeding, a digestibility trial for 7 days was conducted. Rumen liquor and blood samples were collected at the end of the experiment. The DM intake of experimental animals did not differ significantly $(\mathrm{P}>0.05)$. Ruminal $\mathrm{pH}$, ammonia nitrogen, total nitrogen, TCA-N and total volatile fatty acids were within the normal range under the $T_{0}, T_{1}$ and $T_{2}$ groups, respectively, and differed significantly $(\mathrm{P}<0.05)$ from each other. However, non protein nitrogen in the SRL did not differ significantly from each other. There was significant $(\mathrm{P}<0.05)$ reduction in acetate and butyrate concentrations and increase in propionate concentration in $T_{1}$ and $T_{2}$ groups, as compared to $\mathrm{T}_{0}$ group. Acetate to propionate $(\mathrm{A}: \mathrm{P})$ ratio was also decreased in the yeast supplemented groups, as compared to control. Animals receiving supplemental yeast cultures in $T_{1}$ and $T_{2}$ groups tended to have significantly $(\mathrm{P}<0.05)$ higher total anaerobic bacteria and cellulolytic bacteria concentrations in ruminal fluid than animals in $\mathrm{T}_{0}$ group.

The serum glucose was significantly $(\mathrm{P}<0.05)$ higher in $\mathrm{T}_{1}$ and $\mathrm{T}_{2}$ groups, as compared to $\mathrm{T}_{0}$ group. The average digestibility coefficients 
of nutrients for DM, OM, CP, CF, NDF, ADF, cellulose and hemicellulose were significantly $(\mathrm{P}<0.05)$ higher in treatment groups $\left(\mathrm{T}_{1}\right.$ and $\left.\mathrm{T}_{2}\right)$ than the control $\left(\mathrm{T}_{0}\right)$, except those for EE and NFE. The serum enzymes aspartate amino-transferase (AST), alanine amino-transferase (ALT) and alkaline phosphatase (ALP) did not differ within groups. Yeast supplementation did not adversely influence red blood cells, PCV and white blood cells, except a significant $(\mathrm{P}<0.05)$ improvement in haemoglobin concentration. The results indicated that inclusion of live yeast culture in 50:50 concentrates: wheat straw based TMR resulted in improved rumen fermentation and digestibility of nutrients, without affecting bio-chemical profile in Kankrej cows.

Copy Right, IJAR, 2016,. All rights reserved.

\section{Introduction:-}

The Kankrej is one of the largest and heaviest Indian breeds of cattle and are prized as powerful draft animals and are moderate milk producers. In Asia, they are more created in the Western and Northern India (Joshi and Phillips, 1953). Guzerat cattle breed is also developed in Brazil from Kankrej cattle imported from India. In United States, this race with Nellore and Gir, are three major Indian breeds that have had the most important impact on American cattle breeding. Moreover, Kankrej is the most important zebu breed for the formation of American Brahman cattle (Mason, 1996). They show the usual advantages of Zebu cattle in the tropical and semi-tropical environment, good heat tolerance and pest resistance (Garg et al., 2012). The use of yeast cultures to improve production efficiency and the underlying mechanisms for such improvement have attracted increasing attention during recent years (Williams and Newbold, 1990). Yeast cells are known to be a rich source of vitamins, enzymes and some unidentified cofactors that are helpful in increasing microbial activity in the rumen (Dawson et al., 1990 and Williams et al., 1991); hence, yeast culture supplementation has been shown to improve the growth rate (Panda et al., 1995) and feed conversion efficiency (Mir and Mir, 1994). Several workers (Williams, 1989; Williams et al., 1991; Singh et al., 1998 and Lila et al., 2004) have reported that dietary yeast culture supplements produce a range of effects in the rumen including increased $\mathrm{pH}$, increased ruminal concentration of volatile fatty acids and acetate: propionate ratio (Alshaikh et al., 2002), decreased methane production and increased total number of microorganisms and cellulolytic bacteria, others have demonstrated no effect of yeast culture supplementation on ruminal $\mathrm{pH}$, ammoniaN and VFA patterns (Adams et al., 1995; Robinson and Garrett, 1999 and Chaudhary et al., 2008). The objectives of the following study were to examine the effect of supplementing yeast culture from two different commercial sources on the rumen fermentation, nutrient digestibility and bio-chemical profile in Kankrej cows.

\section{Subjects and methods:-}

All experimental procedures were approved by the Institutional Animal Ethics Committee (IAEC) of the Faculty of Veterinary and Animal Science, Anand Agricultural University, Anand, Gujarat, India and were carried out by experienced technical experts.

\section{Selection, feeding and management of experimental animals:-}

Based on the results of in vitro studies, probiotic strains YC-1026 and YC-1077 were incorporated @ 15 and $1.5 \mathrm{~g} / \mathrm{day}$, respectively in TMR, to study the effect of supplementing these strains of probiotics on ruminal fermentation, digestibility of nutrients and bio-chemical profile in Kankrej cows. The feeding trial was conducted for 40 days (excluding 10 days pre-experimental feeding) at Animal Nutrition Research Station farm. Fifteen Kankrej cows were divided into three equal groups of five animals in each group, based on age and body weight: i.e. $\mathrm{T}_{0}$ (Control) group with no probioics, $\mathrm{T}_{1}$ group (YC-1026) and $\mathrm{T}_{2}$ group (YC-1077). Animals in control group were fed TMR without probiotics and those in experimental groups were fed TMR formulated with probiotics level selected on the basis of results of in vitro studies. All the animals were fed TMR with or without probiotics to meet their nutrients requirement per NRC (2001) standard. Individual feeding of all the animals was followed. The animals were let loose for exercise for two hours in the morning and one hour in the afternoon under controlled conditions, during which they had free access to fresh, wholesome drinking water. De-worming of all the animals were carried out using broad spectrum anthelmintic before initiation of the experiment. 


\section{Digestion trial:-}

After 40 days of experimental feeding, a digestion trial for 7 days was conducted to determine digestibility of the nutrients. A proper record of feed consumed, refusal and feces voided by each cow was maintained during the trial period. The chemical analysis of preserved samples of TMR, leftover and feces were carried out as per AOAC (1995) methods, neutral detergent fibre (NDF) and acid detergent fibre (ADF) were determined as per Van Soest et al. (1991) for calculation of digestibility coefficients.

\section{Rumen pH:-}

About $250 \mathrm{ml}$ of rumen liquor was collected from each animal, using a stomach tube and employing suction (Lane et al., 1968). The rumen liquor was immediately brought to the laboratory and strained through four layers of cheese cloth. The $\mathrm{pH}$ of SRL was determined immediately after collection using portable digital $\mathrm{pH}$ meter.

\section{Nitrogen fractions and total volatile fatty acids:-}

The samples of SRL were analyzed for ammonia-N (Pearson and Smith, 1943) and total-N by Kjeldahl's method. Soluble-N in supernatant of SRL after centrifuging was estimated by Kjeldahl's method and non protein-nitrogen estimated by Trichloro-acetic acid precipitation of SRL and estimating the $\mathrm{N}$ content of supernatant by Kjeldahl's method. The concentration of total VFA was determined in SRL by the steam distillation method (Barnett and Reid, 1957), using Markham micro-distillation apparatus.

\section{Fractions of total VFAs:-}

Volatile fatty acids were estimated using Nucon-5765 gas chromatograph equipped with a double flame ionization detector as per the method described by Barnett and Reid (1957). The glass column (6 ft length and $1.8 \mathrm{~mm}$ diameter) packed with Chromosorb 101 was used for the estimation of VFAs. The gas flows for nitrogen, hydrogen and air were 30,30 and $320 \mathrm{ml} / \mathrm{min}$, respectively. Temperature of injector oven, column oven and detector was $270^{\circ} \mathrm{C}, 172^{\circ} \mathrm{C}$ and $270^{\circ} \mathrm{C}$, respectively. Samples were prepared by adding $0.2 \mathrm{ml}$ of $25 \%$ meta-phosphoric acid per $\mathrm{ml}$ of SRL, allowing it to stand for $2 \mathrm{~h}$ followed by centrifugation at $4000 \mathrm{rpm}$ for $5 \mathrm{~min}$. Supernatant was used for estimation of VFA. Standard VFA mixture was prepared by mixing stock solutions (each of $25 \mathrm{mg} / \mathrm{ml}$ concentration) of standard VFAs and water in following amounts: acetic acid $1.68 \mathrm{ml}$; propionic acid $0.48 \mathrm{ml}$; butyric acid $0.24 \mathrm{ml}$; isobutyric acid $0.12 \mathrm{ml}$; valeric acid $0.12 \mathrm{ml}$; isovaleric acid $0.12 \mathrm{ml}$; distilled water $7.24 \mathrm{ml}$ to obtain final concentration of acetic acid 7.0; propionic acid 1.62; butyric acid 0.68; isobutyric acid 0.34; valeric acid 0.29 and isovaleric acid $0.29 \mathrm{mM} / 100 \mathrm{ml}$. The mixture was stored in deep freeze until further analysis.

\section{Total bacterial counts in the SRL:-}

Total anaerobic bacteria count was determined on roll tubes, using complete carbohydrate agar prepared with energy-depleted ruminal fluid (Allison et al., 1979) and counted after $5 \mathrm{~d}$ of incubation at $37^{\circ} \mathrm{C}$. Cellulolytic bacteria were enumerated using the most probable numbers procedure in cellulose broth after $14 \mathrm{~d}$ of incubation at $37^{\circ} \mathrm{C}$ (Bryant et al., 1958).

\section{Haemato-biochemical parameters:-}

At the end of experimental feeding, blood samples from all animals were collected in $10 \mathrm{ml}$ vacuunette tubes early in the morning before feeding from jugular vein, taking all aseptic precautions, for estimation of different haematobiochemical constituents. A set of tubes was allowed for clotting for separation of serum. The serum concentrations of total protein, albumin, globulin and glucose, alanine aminotransferase (ALT/SGPT), aspartate aminotransferase (AST/SGOT) and alkaline phosphatase (AKP) were estimated using Semi Automatic Analyzer for clinical chemistry test (Model 3000 EVOLUION) of Coral Clinical Systems. The commercial diagnostic kits for analysis were procured from CREST Bio-Systems Ltd., Goa, India. Another set of blood samples was used to measure haemoglobin, packed cell volume, red blood cells and white blood cells, using Automatic Hematology Analyzer (Model PE 6000).

\section{Statistical analysis:-}

The data generated during the experiment were subjected to one way analysis of variance as per the methods of Snedecor and Cochran (1994), with the help of SPSS package programme (SPSS 9.00 software for Windows, SPSS Inc., Chicago, IL). 


\section{Results and discussion:-}

The chemical composition and fiber fractions (NDF, ADF), cellulose and hemi-cellulose of wheat straw based total mixed ration offered to experimental animals are summarized in Table 1. It was within the normal range.

Table 1:- Chemical composition of TMRs offered (\% on DM basis) to animals

\begin{tabular}{|l|c|c|c|}
\hline Parameter & $\begin{array}{c}\mathbf{T}_{\mathbf{0}} \text { Group } \\
\text { (Control) }\end{array}$ & $\begin{array}{c}\mathbf{T}_{\mathbf{1}} \text { Group } \\
\text { (YC-1026) }\end{array}$ & $\begin{array}{c}\mathbf{T}_{\mathbf{2}} \text { Group } \\
\text { (YC-1077) }\end{array}$ \\
\hline Moisture (\%) & 15.20 & 16.30 & 15.40 \\
\hline Crude protein (\%) & 11.39 & 11.76 & 11.61 \\
\hline Ether extract (\%) & 2.31 & 2.38 & 2.30 \\
\hline Crude fibre (\%) & 25.92 & 26.93 & 45.36 \\
\hline NFE (\%) & 45.54 & 44.78 & 14.11 \\
\hline Total ash (\%) & 15.04 & 14.15 & 85.89 \\
\hline OM (\%) & 84.96 & 85.85 & 7.92 \\
\hline Acid insoluble ash (\%) & 8.62 & 7.96 & 66.96 \\
\hline NDF (\%) & 67.43 & 67.59 & 38.39 \\
\hline ADF (\%) & 38.77 & 36.25 & 26.34 \\
\hline Cellulose (\%) & 26.80 & 26.10 & 32.45 \\
\hline Hemi-cellulose (\%) & 33.84 & 32.93 & 0.47 \\
\hline Calcium (\%) & 0.49 & 0.46 & 0.58 \\
\hline Phosphorus (\%) & 0.70 & 0.60 & \\
\hline
\end{tabular}

Effect of supplementing yeast culture on dry matter intake:-

The average dry matter intake of animals in $\mathrm{T}_{0}, \mathrm{~T}_{1}$ and $\mathrm{T}_{2}$ groups was $8.82 \pm 0.53,8.64 \pm 0.50$ and $8.88 \pm 0.63 \mathrm{~kg} / \mathrm{day}$ and when expressed as $\mathrm{kg} / 100 \mathrm{~kg}$ body weight was $3.00 \pm 0.03,2.96 \pm 0.05$ and $3.01 \pm 0.09$ and the same in terms of $\mathrm{g} / \mathrm{kg} \mathrm{W}^{0.75}$ was recorded as $124.12 \pm 1.51,122.12 \pm 1.51$ and $124.29 \pm 3.58$ (Table 2). The DM intake of experimental animals did not differ significantly $(\mathrm{P}>0.05)$. The results of the present study are in agreement with the reports of Pandey and Agrawal (2001b), Isik et al. (2004), Chaudhary et al. (2008), Francia et al. (2008), Hucko et al. (2009) and Hossain et al. (2012). However, Grieve (1979), Mutsvangwa (1992), Malik and Sharma (1998), Reddy and Bhima (2003), Kumar and Reddy (2004) and Laborde (2008) reported significantly higher DMI in group of animals supplemented with YC.

Table 2:- Average dry matter intake of experimental animals during digestion trial

\begin{tabular}{|l|c|c|c|}
\hline \multirow{2}{*}{\multicolumn{1}{|c|}{ Attributes }} & \multicolumn{3}{c|}{ Treatments } \\
\cline { 2 - 4 } & $\mathbf{T}_{\mathbf{0}}$ & $\mathbf{T}_{\mathbf{1}}$ & $\mathbf{T}_{\mathbf{2}}$ \\
\hline Average DMI $(\mathrm{kg} / \mathrm{day})$ & $8.82 \pm 0.53$ & $8.64 \pm 0.50$ & $8.88 \pm 0.63$ \\
\hline DMI $(\mathrm{kg} / 100 \mathrm{~kg} \mathrm{BW})$ & $3.00 \pm 0.03$ & $2.96 \pm 0.05$ & $3.01 \pm 0.09$ \\
\hline DMI $\left(\mathrm{g} / \mathrm{kg} \mathrm{W} \mathrm{N}^{0.75}\right)$ & $124.12 \pm 1.51$ & $122.19 \pm 1.01$ & $124.29 \pm 3.58$ \\
\hline
\end{tabular}

Schingoethe et al. (2004) recorded that the dry mater intake of cows was unaffected by the treatment with yeast culture @ $60 \mathrm{~g} / \mathrm{day}$, when supplied through feed. Phondba et al. (2009) also reported the DM intake in crossbred cows was not affected by supplementing probiotic feed supplement @ $10 \mathrm{~g} / \mathrm{head} / \mathrm{day}$ and @ $20 \mathrm{~g} / \mathrm{head} / \mathrm{day}$, as top dressing over concentrate mixture. Zhang et al. (2000) also recorded $1.8 \%(0.36 \mathrm{~kg})$ lower dry matter intake in a group, which was supplemented with Saccharomyces cerevisiae @ 10/cow/day than the control cows. In agreement with that, some studies with lactating animals found no response in dry matter intake (Arambel and Kent, 1990; Piva et al., 1993; Wohlt et al., 1998; Soder and Holden, 1999; Bagheri et al., 2009 and Ondarza et al., 2011). Harrison et al. (1988) explained this situation such that the addition of yeast cultures to the diets of lactating cows increased total concentrations of cellulolytic bacteria in the rumen, but this increase may have not affected total fiber digestion or dry matter intake. This result is contrary to that of Desnoyers et al. (2009), Williams et al. (1991), Wohlt et al. (1991), Dawson and Tricarico (2002) and Stella et al. (2007), who reported that yeast supplementation increased DM intake of experimental cows.

\section{Effect of YC supplementation on rumen parameters:-}

Average values for ruminal $\mathrm{pH}$, total nitrogen, ammonia nitrogen, non protein nitrogen, TCA-N and total volatile fatty acid of experimental animals during different hours of post feeding are summarized in Table 3. 


\section{Ruminal pH:-}

The average $\mathrm{pH}$ in SRL of $\mathrm{T}_{0}, \mathrm{~T}_{1}$ and $\mathrm{T}_{2}$ groups was $6.40,6.50$ and 6.52 , respectively, and were statistically significant between treatments (Table 3). The $\mathrm{pH}$ of SRL decreased up to $4^{\text {th }} \mathrm{h}$ of post feeding, again increased at $6^{\text {th }} \mathrm{h}$ post feeding indicating that the $\mathrm{pH}$ of SRL during periods differed significantly $(\mathrm{P}<0.05)$. Pandey and Agrawal (2001a), Chaudhary et al. (2008) and Thrune et al. (2009) found increase in ruminal $\mathrm{pH}$ significantly $(\mathrm{P}<0.05)$ in yeast supplemented group. However, Panda et al. (1999), Rao et al (2001), Laborde (2008), Tripathi et al. (2008), Lascano and Heinrichs (2009), Hucko et al. (2009) found no differences among treatment groups in rumianl pH on yeast supplementation. It is likely that the yeast strain's positive effects on rumen $\mathrm{pH}$ were due to inhibiting the growth of lactate-producing bacteria while stimulating the growth of lactate-utilizing bacteria, thus leading to an overall decrease in lactate accumulation. Live yeast has been shown to increase rumen $\mathrm{pH}$ in a number of studies with varying levels of starch in the diets. Guedes et al. (2008) found that live yeast reduced rumen $\mathrm{pH}$ variation and increased average rumen $\mathrm{pH}$ from 6.41 to 6.55 in non-acidotic cows.

Table 3:- Average ruminal $\mathrm{pH}, \mathrm{NH}_{3}-\mathrm{N}$, total-N, NPN, TCA precipitable- $\mathrm{N}$ and TVFA in different treatment groups

\begin{tabular}{|c|c|c|c|c|c|c|}
\hline \multirow{2}{*}{ Treatment } & \multicolumn{6}{|c|}{ Hours post-feeding } \\
\hline & $\mathbf{0}$ & 2 & 4 & 6 & 8 & Avg. \\
\hline \multicolumn{7}{|c|}{ Ruminal pH } \\
\hline$T_{0}$ & $6.72 \pm 1.23$ & $6.32 \pm 0.81$ & $6.25 \pm 0.42$ & $6.31 \pm 0.11$ & $6.40 \pm 0.33$ & $6.40^{\mathrm{a}}$ \\
\hline $\mathbf{T}_{1}$ & $6.72 \pm 0.06$ & $6.41 \pm 0.06$ & $6.35 \pm 0.11$ & $6.46 \pm 0.05$ & $6.55 \pm 0.05$ & $6.50^{b}$ \\
\hline $\mathbf{T}_{2}$ & $6.81 \pm 0.07$ & $6.81 \pm 0.07$ & $6.45 \pm 0.10$ & $6.48 \pm 0.04$ & $6.56 \pm 0.04$ & $6.52^{\mathrm{b}}$ \\
\hline \multicolumn{7}{|c|}{ Ammonia $-\mathbf{N}(\mathrm{mg} / \mathrm{dl}$ SRL $)$} \\
\hline$T_{0}$ & $7.22 \pm 0.44$ & $15.79 \pm 0.49$ & $20.27 \pm 1.28$ & $13.60 \pm 1.08$ & $7.46 \pm 1.17$ & $12.87^{b}$ \\
\hline $\mathbf{T}_{1}$ & $6.49 \pm 0.31$ & $14.06 \pm 0.94$ & $15.18 \pm 2.66$ & $10.96 \pm 2.05$ & $4.83 \pm 0.38$ & $10.30^{\mathrm{a}}$ \\
\hline $\mathbf{T}_{2}$ & $6.81 \pm 0.81$ & $14.34 \pm 0.94$ & $16.64 \pm 1.84$ & $12.40 \pm 1.33$ & $5.42 \pm 0.63$ & $11.12^{\mathrm{a}}$ \\
\hline \multicolumn{7}{|c|}{ Total Nitrogen $(\mathrm{mg} / \mathrm{dl}$ SRL) } \\
\hline$T_{0}$ & $71.96 \pm 4.40$ & $110.04 \pm 6.36$ & $97.16 \pm 8.86$ & $93.52 \pm 7.51$ & $91.56 \pm 3.33$ & $92.85^{\mathrm{a}}$ \\
\hline $\mathbf{T}_{1}$ & $80.92 \pm 6.44$ & $117.60 \pm 4.75$ & $124.60 \pm 7.26$ & $115.64 \pm 8.06$ & $103.04 \pm 9.19$ & $108.36^{b}$ \\
\hline $\mathbf{T}_{2}$ & $82.60 \pm 7.08$ & $126.84 \pm 7.60$ & $127.40 \pm 3.86$ & $110.04 \pm 6.02$ & $110.88 \pm 8.06$ & $111.55^{b}$ \\
\hline \multicolumn{7}{|c|}{ Non Protein Nitrogen $(\mathrm{mg} / \mathrm{dl}$ SRL) } \\
\hline $\mathbf{T}_{\mathbf{0}}$ & $26.32 \pm 1.22$ & $26.60 \pm 2.12$ & $31.36 \pm 3.56$ & $26.32 \pm 1.74$ & $33.60 \pm 5.63$ & 28.78 \\
\hline$T_{1}$ & $25.76 \pm 0.84$ & $27.72 \pm 1.74$ & $35.56 \pm 1.44$ & $31.64 \pm 3.05$ & $36.12 \pm 1.72$ & 31.36 \\
\hline $\mathbf{T}_{2}$ & $27.72 \pm 1.49$ & $28.84 \pm 1.96$ & $32.48 \pm 2.10$ & $32.48 \pm 2.56$ & $36.12 \pm 1.03$ & $\mathbf{3 1 . 5 3}$ \\
\hline \multicolumn{7}{|c|}{ TCA Precipitable Nitrogen (mg/dl SRL) } \\
\hline $\mathbf{T}_{0}$ & $45.92 \pm 5.43$ & $83.44 \pm 4.98$ & $65.80 \pm 8.91$ & $67.20 \pm 6.84$ & $57.90 \pm 7.31$ & $54.67^{\mathrm{a}}$ \\
\hline $\mathbf{T}_{1}$ & $55.16 \pm 6.49$ & $89.88 \pm 4.86$ & $89.04 \pm 8.22$ & $84.00 \pm 7.73$ & $66.92 \pm 11.81$ & $64.64^{b}$ \\
\hline $\mathbf{T}_{2}$ & $54.88 \pm 8.06$ & $98.00 \pm 8.62$ & $94.92 \pm 5.86$ & $77.56 \pm 6.02$ & $74.76 \pm 7.19$ & $66.82^{b}$ \\
\hline \multicolumn{7}{|c|}{ Total Volatile Fatty Acids (mM/ml SRL) } \\
\hline $\mathbf{T}_{0}$ & $7.83 \pm 5.14$ & $9.39 \pm 5.17$ & $11.94 \pm 5.25$ & $10.74 \pm 5.03$ & $9.72 \pm 5.03$ & $9.92^{\mathrm{a}}$ \\
\hline $\mathbf{T}_{1}$ & $10.23 \pm 4.12$ & $15.39 \pm 7.79$ & $17.97 \pm 7.68$ & $13.17 \pm 6.61$ & $11.52 \pm 5.12$ & $13.65^{b}$ \\
\hline $\mathbf{T}_{2}$ & $10.08 \pm 4.04$ & $16.68 \pm 6.32$ & $18.93 \pm 6.21$ & $13.95 \pm 2.60$ & $10.53 \pm 5.69$ & $\mathbf{1 4 . 0 3}^{\mathrm{b}}$ \\
\hline
\end{tabular}

\section{Ammonia nitrogen:-}

The average ammonia nitrogen in $\mathrm{SRL}$ in $\mathrm{T}_{0}, \mathrm{~T}_{1}$ and $\mathrm{T}_{2}$ groups was $12.87,10.30$ and $11.12 \mathrm{mg} / \mathrm{dl}$, respectively. The treatment differed significantly $(\mathrm{P}<0.05)$ from each other in this respect. Also, the concentration of ammonia nitrogen differed significantly during different periods. The control group $\mathrm{T}_{0}$ recorded significantly $(\mathrm{P}<0.05)$ higher ammonia nitrogen than $T_{1}$ group. The animals under $T_{2}$ group had an intermediate position between $T_{0}$ and $T_{1}$ groups. Ammonia nitrogen levels attained peak at $4 \mathrm{~h}$ post feeding and then declined afterwards up to $8 \mathrm{~h}$ post feeding with the same pattern in all treatment groups. $\mathrm{NH}_{3}-\mathrm{N}$ was depressed significantly $(\mathrm{P}<0.05)$ due to supplementation of live yeast in $T_{1}$ and $T_{2}$ groups. In present study, the yeast supplementation in animal's diets changed the pattern of the end products of rumen fermentation, suggesting a shift in metabolic activities of rumen microflora. The results of the present investigation are corroborated by the findings of Lascano and Heinrichs (2009), Kumar et al. (1997) and Erasmus et al. (1992) who reported 10\% reduction in rumen ammonia concentration and 9.4\% more non ammonia nitrogen (NAN) at duodenum by $\mathrm{YC}$ supplementation. A decrease in $\mathrm{NH}_{3}$ concentration is attributed to ruminal 
microbial proliferation, due to the increase of microbial use of available $\mathrm{NH}_{3}$ (Pinos-Rodriguez et al., 2008). However, Panda et al. (1995), Panda et al. (1999), Rao et al. (2001), Rao et al. (2003), Chaudhary et al. (2008), Laborde (2008) and Tripathi et al. (2008) found non-significant differences among treatment groups but $\mathrm{NH}_{3}-\mathrm{N}$ levels tend to be lower in yeast supplemented group. Thus, it could be inferred that live yeast (Saccharomyces cerevisiae) supplementation in ration decreased $\mathrm{NH}_{3}-\mathrm{N}$ level because of its utilization for microbial protein synthesis.

\section{Total nitrogen:-}

The average total nitrogen in SRL was $92.85,108.36$ and $111.55 \mathrm{mg} / \mathrm{dl}$ in $\mathrm{T}_{0}, \mathrm{~T}_{1}$ and $\mathrm{T}_{2}$ groups, respectively. There was significant $(\mathrm{P}<0.05)$ higher total nitrogen in $\mathrm{T}_{1}$ and $\mathrm{T}_{2}$ groups, as compared to $\mathrm{T}_{0}$ (control) group. Pandey and Agrawal (2001a) found significantly higher total nitrogen values for animals fed probiotics. It was evident that group $\mathrm{T}_{0}, \mathrm{~T}_{1}$ and $\mathrm{T}_{2}$ groups manifested same pattern of total-N concentration showing no difference within the groups. The peak concentration was found at $4 \mathrm{~h}$ post feeding and then declined up to $8^{\text {th }} \mathrm{h}$ post feeding. The periodical changes in total nitrogen were found to be significant $(\mathrm{P}<0.05)$.

\section{Non protein nitrogen:-}

The result revealed that average non protein nitrogen in SRL of $\mathrm{T}_{0}, \mathrm{~T}_{1}$ and $\mathrm{T}_{2}$ groups was $28.78,31.36$ and 31.53 $\mathrm{mg} / \mathrm{dl}$, respectively. The highest concentration was found in $\mathrm{T}_{2}$ group, but the treatment groups did not differ from each other. Kumar et al. (1997) reported the similar trend, whereas, Pandey and Agrawal (2001a) found significantly higher values in the group of animals supplemented with probiotics. The treatment and interaction between treatments and intervals did not differ significantly. Maximum non protein nitrogen concentration was recorded at 4 $\mathrm{h}$ and then declined up to $8 \mathrm{~h}$ post feeding with the same pattern in all the three treatment groups. Pandey and Agrawal (2001a) and Chaudhary et al. (2008) reported significantly $(\mathrm{P}<0.05)$ higher rumen $\mathrm{pH}$, total $\mathrm{N}$ and NPN in yeast supplemented group.

\section{TCA precipitable nitrogen:-}

The results revealed that average TCA nitrogen in SRL of $\mathrm{T}_{0}, \mathrm{~T}_{1}$ and $\mathrm{T}_{2}$ groups was 54.67, 64.64 and $66.82 \mathrm{mg} / \mathrm{dl}$, respectively (Table 3). There was significant higher TCA-N in $T_{1}$ and $T_{2}$ groups, as compared to $T_{0}$ group. Pandey and Agrawal (2001a) reported significantly higher values in the group of animals supplemented with probiotics, whereas, Kumar et al. (1997) found no effect of TCA-N values in the animals supplemented with live yeast. The treatment and interaction between treatments and intervals found differed significantly $(\mathrm{P}<0.05)$. Maximum TCA-N concentration was recorded at $2 \mathrm{~h}$ and then declined up to $8 \mathrm{~h}$ post feeding with the same pattern in all the three treatment groups.

\section{Total volatile fatty acids (TVFA):-}

The maximum TVFA concentration was found at $4 \mathrm{~h}$ and then declined up to $8 \mathrm{~h}$ of post feeding with the same pattern in all treatment groups. The average TVFA concentration in SRL was 9.92, 13.65 and $14.03 \mathrm{mM}$ in $\mathrm{T}_{0}, \mathrm{~T}_{1}$ and $\mathrm{T}_{2}$ groups, respectively. The highest concentration was found in $\mathrm{T}_{2}$ group. The treatment and the periodical changes in TVFA were found to be significant $(\mathrm{P}<0.05)$. These results agreed with the review of Robinson and Garret (1999), which showed an average increase in $\mathrm{pH}(1.6 \%)$ and an overall increase in TVFA (5.4\%). Kumar et al. (1997), Rao et al. (2003), Quigley et al. (2007), Laborde (2008) and Lascano and Heinrichs (2009) also reported that addition of YC to the diet significantly increased the concentration of TVFA. However, Dawson et al (1990), Yadav et al. (1996) and Chaudhary et al. (2008) reported that concentration of TVFA was not altered in the continuous cultures and rumen of steers and buffalo calves. Thus, the role of live yeast cell is as a rumen microbial activity enhancer and capable of influencing some aspects of rumen fermentation processes to increase the outcome of TVFA's production fortifying the total number of anaerobic bacteria, particularly cellulolytic bacteria and to plunge $\mathrm{NH}_{3}-\mathrm{N}$. Thus, inclusion of live yeast (Saccharomyces cerevisiae) in the ration had positive influence on ruminal TVFA concentration. It may be due to ability of yeast to provide soluble growth factors that stimulate growth of cellulolytic bacteria and cellulose digestion (Callaway and Martin, 1997).

\section{Molar proportion of volatile fatty acids (VFA) in SRL:-}

The results revealed that average molar proportion of acetate, propionate and butyrate, respectively was $59.17 \pm 0.76$, $23.34 \pm 0.41$ and $12.18 \pm 0.33 \mathrm{mM}$ in $\mathrm{T}_{0}$ group, $54.21 \pm 0.23,28.90 \pm 0.63$ and $11.69 \pm 0.48 \mathrm{mM}$ in $\mathrm{T}_{1}$ group and $54.50 \pm 0.62,29.14 \pm 0.81$ and $11.23 \pm 0.16 \mathrm{mM}$ in $\mathrm{T}_{2}$ group (Table 4). There was significant $(\mathrm{P}<0.05)$ reduction in acetate and butyrate concentrations and increase in propionate concentration in $T_{1}$ and $T_{2}$ groups, as compared to $T_{0}$ group. Acetate to propionate (A:P) ratio was also decreased in the yeast supplemented groups, as compared to control group. The dietary yeast culture strains YC 1026 and YC-1077 supplementation to experimental animals resulted in 
decreased molar proportion of acetate and butyrate, acetate to propionate ratio and increased molar proportion of propionate. Harrison et al. (1988) found decreased molar proportion of acetate and acetate to propionate ratio and increased molar proportion of propionate in rumen fluid of Holstein cows supplemented with a yeast culture containing $S$. cerevisiae. The yeast supplementation to animals changed the pattern of the end products of ruminal fermentation, suggesting a shift in metabolic activities of ruminal microflora (Kobayashi et al., 1995).

Table 4:- Effect of supplementing yeast cultures on molar proportion of VFAs (mM) and total bacteria counts in SRL in different treatment groups

\begin{tabular}{|l|c|c|c|}
\hline Attributes & $\mathbf{T}_{\mathbf{0}}(\mathbf{C o n t r o l})$ group & $\mathbf{T}_{\mathbf{1}}(\mathbf{Y} \mathbf{C}-1026)$ group & $\mathbf{T}_{\mathbf{2}}(\mathbf{Y} \mathbf{C - 1 0 7 7})$ group \\
\hline Acetate & $59.17^{\mathrm{b}} \pm 0.76$ & $54.21^{\mathrm{a}} \pm 0.43$ & $54.50^{\mathrm{a}} \pm 0.62$ \\
\hline Propionate & $23.34^{\mathrm{a}} \pm 0.41$ & $28.90^{\mathrm{b}} \pm 0.63$ & $29.14^{\mathrm{b}} \pm 0.81$ \\
\hline Iso-butyrate & $1.37 \pm 0.04$ & $1.31 \pm 0.05$ & $1.34 \pm 0.05$ \\
\hline Butyrate & $12.18^{\mathrm{b}} \pm 0.33$ & $11.69^{\mathrm{a}} \pm 0.48$ & $11.23^{\mathrm{a}} \pm 0.16$ \\
\hline Iso-valerate & $1.59 \pm 0.02$ & $1.52 \pm 0.07$ & $1.53 \pm 0.07$ \\
\hline Valerate & $2.35 \pm 0.08$ & $2.36 \pm 0.15$ & $5.27 \pm 0.24$ \\
\hline Iso-acids & $5.32 \pm 0.10$ & $5.19 \pm 0.24$ & $1.88^{\mathrm{a}} \pm 0.07$ \\
\hline A:P ratio & $2.54^{\mathrm{b}} \pm 0.08$ & $1.88^{\mathrm{a}} \pm 0.04$ & $11.01^{\mathrm{b}} \pm 0.08$ \\
\hline $\begin{array}{l}\text { Total anaerobic bacteria } \\
\left(\log _{10} \text { value/ml) }\right.\end{array}$ & $8.71^{\mathrm{a}} \pm 0.27$ & $10.40^{\mathrm{b}} \pm 0.25$ & $9.15^{\mathrm{b}} \pm 0.12$ \\
\hline $\begin{array}{l}\text { Total cellulolytic bacteria }\left(\log _{10}\right. \\
\text { value/ml) }\end{array}$ & $7.79^{\mathrm{a}} \pm 0.17$ & $8.98^{\mathrm{b}} \pm 0.04$ & \\
\hline
\end{tabular}

${ }^{a, b}$ Means bearing different superscripts in a row differ significantly at $P<0.05$

Total anaerobic bacteria and cellulolytic bacteria counts in SRL:-

Total anaerobic bacteria concentrations $\left(\log _{10} \mathrm{ml}^{-1}\right)$ in SRL were 8.71, 10.40 and 11.01 in $\mathrm{T}_{0}, \mathrm{~T}_{1}$ and $\mathrm{T}_{2}$ groups, respectively. Concentrations of cellulolytic bacteria were 7.79, 8.98 and 9.15 in $\mathrm{T}_{0}, \mathrm{~T}_{1}$ and $\mathrm{T}_{2}$ groups, respectively (Table 4). Animals receiving supplemental $\mathrm{YC}$ in $\mathrm{T}_{1}$ and $\mathrm{T}_{2}$ groups tended to have significantly $(\mathrm{P}<0.05)$ higher total anaerobic bacteria and cellulolytic bacteria concentrations in SRL than animals in $\mathrm{T}_{0}$ group. Increased numbers of total anaerobic bacteria and cellulolytic bacteria with addition of YC culture are in agreement with other studies (Dawson and Newman, 1987 and Weidmeier et al., 1987). Greater concentrations of total anaerobic bacteria and cellulolytic bacteria may explain why ruminal ammonia concentrations are lower in animals fed YC (Mosoni et al., 2007; Chaucheyras-Durand and Fonty 2001). Ammonia is the preferred source of $\mathrm{N}$ for a large proportion of the ruminal microbial population (Bryant and Robinson, 1963) and incorporation of ammonia into ruminal bacteria has been demonstrated by Mathison and Milligan (1971). An increase in the number of total viable bacteria (Koul et al., 1998) and cellulolytic bacteria (Weidmeier et al., 1987; Harrison et al., 1988 and Koul et al., 1998) were also observed when the yeast culture was used as a feed supplement to cattle with already developed rumen. Lower concentrations of ammonia in the rumen of animals fed YC may reflect increased transportation of ammonia into microbial protein. Cellulolytic bacterial activity accounts for the majority of fibre digestion in the rumen. These bacteria capture most of the energy from fibre when $\mathrm{pH}$ is maintained at or above $\mathrm{pH} \mathrm{6.0.} \mathrm{By} \mathrm{nurturing} \mathrm{a} \mathrm{healthy,}$ dynamic population of cellulolytic or fibre digesting bacteria, yeast culture helps increase fibre digestibility.

\section{Haemato-biochemical and enzymatic profile of experimental animals:-}

Blood metabolites are frequently used to monitor the metabolic health status of dairy cows (Ametaj et al., 2009). The average haemato-biochemical and enzymatic profile of experimental animals in $\mathrm{T}_{0}, \mathrm{~T}_{1}$ and $\mathrm{T}_{2}$ groups are presented in Table 5.

\section{Total protein:-}

The serum protein level indicates the balance between anabolism and catabolism of proteins in the body. The serum protein level at any given time in turn is a function of hormonal balance, nutritional status, water balance and other factors affecting the state of health. The average total protein $(\mathrm{g} / \mathrm{dl})$ concentration of experimental animals in $\mathrm{T}_{0}, \mathrm{~T}_{1}$ and $\mathrm{T}_{2}$ groups was $6.36 \pm 0.22,6.80 \pm 0.13$ and $6.94 \pm 0.19$, respectively, among which $\mathrm{T}_{1}$ and $\mathrm{T}_{2}$ groups differed significantly $(\mathrm{P}<0.05)$ from $\mathrm{T}_{0}$ group. The animals under $\mathrm{T}_{1}$ group had an intermediate position between $\mathrm{T}_{0}$ and $\mathrm{T}_{2}$ groups. The levels were within the normal range, as reported by Kaneko et al. (1997). Chaudhary et al. (2008) and Hossain et al. (2012) reported similar total protein concentration in control animals and the animals supplemented with probiotics. 
Table 5:- Average haemato-biochemical and enzymatic profile of experimental animals

\begin{tabular}{|l|c|c|c|}
\hline \multirow{2}{*}{ Parameters } & \multicolumn{3}{|c|}{ Treatments } \\
\cline { 2 - 4 } & $\mathbf{T}_{\mathbf{0}}$ & $\mathbf{T}_{\mathbf{1}}$ & $\mathbf{T}_{\mathbf{2}}$ \\
\hline Glucose (mg/dl) & $48.0^{\mathrm{a}} \pm 1.30$ & $64.2^{\mathrm{b}} \pm 1.50$ & $63.2^{\mathrm{b}} \pm 2.13$ \\
\hline Total protein(g/dl) & $6.4^{\mathrm{a}} \pm 0.22$ & $6.8^{\mathrm{b}} \pm 0.13$ & $6.9^{\mathrm{b}} \pm 0.19$ \\
\hline Albumin (g/dl) & $2.5 \pm 0.10$ & $2.4 \pm 0.07$ & $2.5 \pm 0.07$ \\
\hline Globulin (g/dl) & $3.9^{\mathrm{a}} \pm 0.22$ & $4.4^{\mathrm{b}} \pm 0.18$ & $4.5^{\mathrm{b}} \pm 0.19$ \\
\hline ALT/SGPT (U/L) & $38.4 \pm 3.08$ & $38.6 \pm 1.90$ & $36.0 \pm 2.84$ \\
\hline AST/SGOT (U/L) & $59.4 \pm 6.71$ & $63.0 \pm 1.48$ & $62.6 \pm 4.93$ \\
\hline AKP (U/L) & $207.6 \pm 4.68$ & $259.2 \pm 16.01$ & $282.4 \pm 20.98$ \\
\hline Creatinine (mg/dl) & $1.4 \pm 0.08$ & $1.4 \pm 0.06$ & $1.4 \pm 0.04$ \\
\hline Hb (g/dl) & $10.4^{\mathrm{a}} \pm 0.11$ & $11.4^{\mathrm{ab}} \pm 0.46$ & $12.0^{\mathrm{b}} \pm 0.20$ \\
\hline PCV (\%) & $31.2 \pm .49$ & $33.6 \pm 1.24$ & $33.7 \pm 1.24$ \\
\hline RBCs (x10 $\left.{ }^{6}\right)$ & $7.7 \pm 0.23$ & $8.4 \pm 0.27$ & $8.4 \pm 0.32$ \\
\hline WBCs (x10 $\left.{ }^{3}\right)$ & $7.4 \pm 0.41$ & $8.6 \pm 0.48$ & $7.9 \pm 0.16$ \\
\hline
\end{tabular}

${ }^{a, b}$ Means bearing different superscripts in a row differ significantly at $P<0.05$

\begin{abstract}
Albumin:-
The albumin is synthesized by liver and catabolized by wide variety of tissues. Albumin supplies a readily available pool of amino acids to meet the tissue needs depending on nutritional status as its synthesis is diminished during fasting or mal-nutrition, hormonal imbalance and general poor condition of liver (Jain, 1993). The average albumin ( $\mathrm{g} / \mathrm{dl}$ ) concentration in experimental animals in $\mathrm{T}_{0}, \mathrm{~T}_{1}$ and $\mathrm{T}_{2}$ groups was 2.46 $\pm 0.10,2.42 \pm 0.07$ and 2.46 \pm 0.07 , respectively. The treatment groups did not differ significantly $(\mathrm{P}<0.05)$ from each other. The levels were within the normal range reported by Kaneko et al. (1997). Chaudhary et al. (2008) and Hossain et al. (2012) reported similar albumin concentration in control animals and the animals given probiotics.
\end{abstract}

\title{
Globulin:-
}

The serum globulin, especially $\alpha$ and $\beta$ globulin increased due to acute inflammatory conditions, whereas $\gamma$ globulins are responsible for the immune status of the animal (Jain 1993). Thus, the comparable serum globulin levels observed during present study indicates that there was no significant inflammatory change in the body and animals maintained normal immune body status. The average globulin $(\mathrm{g} / \mathrm{dl})$ concentration in experimental animals in $\mathrm{T}_{0}, \mathrm{~T}_{1}$ and $\mathrm{T}_{2}$ groups was $3.90 \pm 0.22,4.38 \pm 0.18$ and $4.48 \pm 0.19$, respectively, among which $\mathrm{T}_{2}$ group was significantly $(\mathrm{P}<0.05)$ higher than $\mathrm{T}_{0}$ group. The animals under $\mathrm{T}_{1}$ group had an intermediate position. The levels were within the normal range, as reported by Kaneko et al. (1997). Chaudhary et al. (2008) and Hossain et al. (2012) reported similar globulin concentration in control animals and the animals given probiotics. However, Piva et al. (1993) reported that glucose, total protein and albumin of blood plasma were not affected by supplementation with yeast culture.

\section{Glucose:-}

The serum glucose level is an indicator of physiological condition of the animals. Glucose represents the synthesis of carbohydrates and is in the form in which carbohydrate is supplied to cell from body fluids. The average glucose

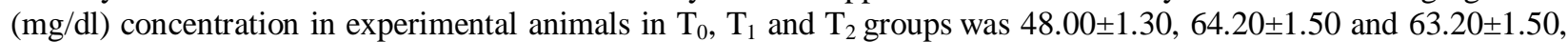
respectively, among which $\mathrm{T}_{1}$ and $\mathrm{T}_{2}$ groups differed significantly $(\mathrm{P}<0.05)$ from $\mathrm{T}_{0}$ group. Chaudhary et al. (2008) and Hossain et al. (2012) reported similar glucose concentration in control animals and the animals given probiotics. However, Putnam et al. (1997) observed that serum glucose was not affected by daily $10 \mathrm{~g}$ yeast culture addition to the diets of lactating cows.

Alanine amino-transferase (ALT)/ Serum glutamic pyruvate transaminase (SGPT):-

Average ALT concentration of experimental animals in $\mathrm{T}_{0}, \mathrm{~T}_{1}$ and $\mathrm{T}_{2}$ groups was 38.40 $\pm 3.08,38.60 \pm 1.90$ and $36.00 \pm 2.84 \mathrm{U} / \mathrm{L}$, respectively. The three groups did not differ significantly $(\mathrm{P}<0.05)$ from each other. The levels were within the normal range, as reported by Kaneko et al. (1997).

Aspartate amino-transferase (AST) / Sreum glutamate oxaloacetate transaminase (SGOT):-

The SGOT activity is commonly seen in many tissues and it is a good marker of soft tissue. SGOT is both cytoplasmic and mitochondrial enzyme which is released even during mild degenerative changes that increase membrane 
permeability (Evans 1988). SGOT level is raised during acute and chronic disorders of liver and muscle damage (Cornelius, 1980 and Pensent, 1983). Because of the presence of AST (SGOT) activity in a number of tissues its serum level will be good marker of soft tissue damage, but precludes its use as an organ specific enzyme (Boyd, 1983). Marked elevation of SGOT preceded by lowered creatinine kinase activity could serve as an indicator of muscle damage (Kramer, 1989). In the present study, the average AST concentration of experimental animals in $\mathrm{T}_{0}$, $\mathrm{T}_{1}$ and $\mathrm{T}_{2}$ groups was 59.40 $\pm 6.71,63.00 \pm 4.93$ and $62.60 \pm 4.93 \mathrm{U} / \mathrm{L}$, respectively. The three groups did not differ significantly $(\mathrm{P}<0.05)$ from each other. The levels were within the normal range as reported by Kaneko et al. (1997).

\section{Alkaline phosphatase (AKP):-}

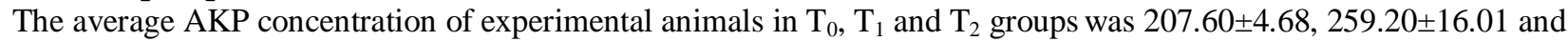
282.40 $\pm 20.98 \mathrm{U} / \mathrm{L}$, respectively. The three groups did not differ significantly from each other. The levels were within the normal range as reported by Kaneko et al. (1997). Hossain et al. (2012) reported that similar AKP levels in animals supplemented with live yeast. Thus, inclusion of live yeast (Saccharomyces cerevisiae) in the ration had no influence on serum enzyme profile.

\section{Serum creatinine:-}

The average creatinine concentration of experimental animals in $\mathrm{T}_{0}, \mathrm{~T}_{1}$ and $\mathrm{T}_{2}$ groups was $1.42 \pm 0.08,1.40 \pm 0.06$ and $1.38 \pm 0.04 \mathrm{mg} / \mathrm{dl}$, respectively. The three groups did not differ significantly from each other. The levels were within the normal range as reported by Kaneko et al. (1997). Thus, inclusion of live yeast (Saccharomyces cerevisiae) in the ration had no influence on serum creatinine concentration.

\section{Haemoglobin (Hb):-}

The average $\mathrm{Hb}(\mathrm{g} / \mathrm{dl})$ concentration of experimental animals in $\mathrm{T}_{0}, \mathrm{~T}_{1}$ and $\mathrm{T}_{2}$ groups was $10.36 \pm 0.1,11.44 \pm 0.46$ and $12.00 \pm 0.20$, respectively, among which $\mathrm{T}_{1}$ and $\mathrm{T}_{2}$ groups differed significantly $(\mathrm{P}<0.05)$ from $\mathrm{T}_{0}$ group. The levels were within the normal range as reported by Kaneko et al. (1997).

\section{Packed cell volume (PCV):-}

The PCV $(\%)$ content of experimental animals in $\mathrm{T}_{0}, \mathrm{~T}_{1}$ and $\mathrm{T}_{2}$ groups was 31.22 $\pm 1.24,33.60 \pm 1.24$ and $33.70 \pm 1.24$, respectively. The three groups did not differ significantly from each other. Lesmeister et al. (2004) and Chaudhary et al. (2008) reported similar PCV\% in control animals and the animals given probiotics.

\section{Red blood cells (RBCs):-}

The average RBCs $\left(\mathrm{x} 10^{6}\right)$ content of experimental animals in $\mathrm{T}_{0}, \mathrm{~T}_{1}$ and $\mathrm{T}_{2}$ groups was $7.72 \pm 0.23,8.37 \pm 0.27$ and $8.44 \pm 0.32$, respectively. The three groups did not differ significantly from each other. Sakine et al. (2011) reported similar RBCs level in control animals and the animals given probiotics.

\section{White blood cells (WBCs):-}

The average WBCs $\left(\times 10^{3}\right)$ content of experimental animals in $\mathrm{T}_{0}, \mathrm{~T}_{1}$ and $\mathrm{T}_{2}$ groups was 7.40 $\pm 0.41,8.56 \pm 0.48$ and $7.90 \pm 0.16$, respectively. The three groups did not differ significantly from each other.

\section{Digestible nutrients:- \\ CP and TDN content of TMRs:-}

The data on content of CP and total digestible nutrients (\%) in TMRs is presented in Table 6. The average content of $\mathrm{CP}$ was $11.39 \pm 0.09,11.76 \pm 0.07$ and $11.61 \pm 0.11 \%$ and $\mathrm{TDN}$ was $50.72 \pm 1.10,53.21 \pm 1.11$ and $54.89 \pm 0.51 \%$ in $\mathrm{T}_{0}, \mathrm{~T}_{1}$ and $\mathrm{T}_{2}$, respectively. The CP content of TMRs was significantly higher $(\mathrm{P}<0.05)$ in $\mathrm{T}_{1}$ group as compared to $\mathrm{T}_{0}$ and $\mathrm{T}_{2}$ groups, whereas, the TDN content of the $\mathrm{T}_{2}$ group was significantly $(\mathrm{P}<0.05)$ higher than $\mathrm{T}_{0}$ and $\mathrm{T}_{1}$ groups.

\section{CP and TDN intake (as the \% of requirement) of animals:-}

The average daily $\mathrm{CP}$ intake as per cent of requirement (NRC, 2001) of experimental animals in $\mathrm{T}_{0}, \mathrm{~T}_{1}$ and $\mathrm{T}_{2}$ groups during digestion trial was $120.96 \pm 5.46,121.14 \pm 6.39$ and $119.63 \pm 7.41 \%$, respectively (Table 6). The treatment groups did not differ statistically $(\mathrm{P}<0.05)$ among themselves. The $\mathrm{CP}$ intake was enough to support the performance of experimental animals. The average daily TDN intake as per cent of requirement of experimental animals in $\mathrm{T}_{0}, \mathrm{~T}_{1}$ and $\mathrm{T}_{2}$ groups during digestion trial was $100.14 \pm 0.43,113.64 \pm 5.98$ and $115.73 \pm 5.38 \%$, respectively. The TDN intake as per cent of requirement in treatment groups was also significantly $(\mathrm{P}<0.05)$ similar. The data on TDN intake as per cent of requirement indicates more than enough intake of TDN to support the performance of experimental animals 


\section{CP and TDN intake of animals:-}

The average daily crude protein intake (CPI) and total digestible nutrients intake (TDNI) of experimental animals of $\mathrm{T}_{0}, \mathrm{~T}_{1}$ and $\mathrm{T}_{2}$ groups, during digestion trial are presented in Table 6 . The daily CP intake of experimental animals of $\mathrm{T}_{0}, \mathrm{~T}_{1}$ and $\mathrm{T}_{2}$ groups, during digestion trial was $818.11 \pm 28.03,848.76 \pm 34.52$ and $860.24 \pm 48.48 \mathrm{~g} / \mathrm{head}$ and $281.38 \pm 14.53,293.46 \pm 15.23$ and $292.64 \pm 10.42$ in terms of $\mathrm{g} / 100 \mathrm{~kg}$ body weight and the same when expressed as $\mathrm{g} /$ $\mathrm{kg} \mathrm{W}^{0.75}$ it was $11.60 \pm 0.44,13.10 \pm 0.48$ and $12.08 \pm 0.27$. The $\mathrm{CP}$ intake of all the three groups was statistically $(\mathrm{P}<0.05)$ similar.

Table 6:- Average nutrient intake of experimental animals

\begin{tabular}{|c|c|c|c|}
\hline \multirow[t]{2}{*}{ Particular } & \multicolumn{3}{|c|}{ Dietary treatments } \\
\hline & $\mathbf{T}_{\mathbf{0}}$ & $\mathrm{T}_{1}$ & $\mathbf{T}_{2}$ \\
\hline Average $\mathrm{CP}$ intake (as \% of requirement) & $120.96 \pm 5.46$ & $121.14 \pm 6.39$ & $119.63 \pm 7.41$ \\
\hline Average TDN intake (as \% of requirement) & $100.14 \pm 0.43$ & $113.64 \pm 5.98$ & $115.73 \pm 5.38$ \\
\hline Average daily $\mathrm{CP}$ intake (g/day) & $818.11 \pm 28.03$ & $848.76 \pm 34.52$ & $860.24 \pm 48.48$ \\
\hline $\mathrm{kg} / 100 \mathrm{~kg}$ body weight & $281.38 \pm 14.53$ & $293.46 \pm 15.23$ & $292.64 \pm 10.42$ \\
\hline${\mathrm{g} / \mathrm{kg} \mathrm{W}^{0.75}}^{0.75}$ & $11.60 \pm 0.44$ & $13.10 \pm 0.48$ & $12.08 \pm 0.27$ \\
\hline Average daily TDN intake (kg/day) & $3.69^{\mathrm{a}} \pm 0.15$ & $4.03^{\mathrm{ab}} \pm 0.20$ & $4.33^{b} \pm 0.15$ \\
\hline $\mathrm{kg} / 100 \mathrm{~kg}$ body weight & $1.27 \pm 0.05$ & $1.39 \pm 0.08$ & $1.49 \pm 0.11$ \\
\hline${\mathrm{g} / \mathrm{kg} \mathrm{W}^{0.75}}^{0}$ & $52.22^{\mathrm{a}} \pm 1.45$ & $57.34^{\mathrm{ab}} \pm 2.51$ & $61.40^{\mathrm{b}} \pm 3.40$ \\
\hline $\begin{array}{l}\text { Average daily digestible dry matter (DDM) intake } \\
\text { (kg/day) }\end{array}$ & $4.90^{\mathrm{a}} \pm 0.31$ & $5.14^{\mathrm{b}} \pm 0.21$ & $5.32^{\mathrm{b}} \pm 0.30$ \\
\hline $\mathrm{kg} / 100 \mathrm{~kg}$ body weight & $1.67^{\mathrm{a}} \pm 0.01$ & $1.77^{\mathrm{b}} \pm 0.04$ & $1.81^{\mathrm{b}} \pm 0.06$ \\
\hline $\mathrm{g} / \mathrm{kg} \mathrm{W}^{0.75}$ & $68.90^{\mathrm{a}} \pm 1.27$ & $72.95^{\mathrm{b}} \pm 0.76$ & $74.66^{b} \pm 1.82$ \\
\hline Average daily DOM intake (kg/day) & $3.44^{\mathrm{a}} \pm 0.15$ & $4.11^{\mathrm{b}} \pm 0.17$ & $4.18^{\mathrm{b}} \pm 0.19$ \\
\hline $\mathrm{kg} / 100 \mathrm{~kg}$ body weight & $1.21^{\mathrm{a}} \pm 0.04$ & $1.42^{\mathrm{b}} \pm 0.05$ & $1.43^{\mathrm{b}} \pm 0.05$ \\
\hline $\mathrm{g} / \mathrm{kg} \mathrm{W}^{0.75}$ & $48.66^{\mathrm{a}} \pm 1.78$ & $58.38^{\mathrm{b}} \pm 1.05$ & $58.86^{\mathrm{b}} \pm 1.06$ \\
\hline
\end{tabular}

${ }^{a, b}$ Means bearing different superscripts in a row differ significantly at $P<0.05$

Pandey and Agrawal (2001b) reported similar CP intake in growing animals given Saccharomyces cerevisiae in the ration. The average daily TDN intake of experimental animals of $\mathrm{T}_{0}, \mathrm{~T}_{1}$ and $\mathrm{T}_{2}$ groups during digestion trial was $3.69 \pm 0.15,4.03 \pm 0.20$ and $4.33 \pm 0.15 \mathrm{~kg} / \mathrm{head}, 1.27 \pm 0.05,1.39 \pm 0.08$ and $1.49 \pm 0.11 \mathrm{~kg} / 100 \mathrm{~kg}$ body weight and in terms of $\mathrm{g} / \mathrm{kg} \mathrm{W}^{0.75}$; it was recorded as $52.22 \pm 1.45,57.34 \pm 2.51$ and $61.40 \pm 3.40$, respectively. The treatment groups $\mathrm{T}_{1}$ and $\mathrm{T}_{2}$ recorded statistically higher $(\mathrm{P}<0.05) \mathrm{TDN}$ intake in terms of $\mathrm{g} / \mathrm{kg} \mathrm{W}^{0.75}$ than $\mathrm{T}_{0}$ group.

\section{Average daily digestible dry matter intake:-}

The average daily digestible dry matter intake (DDMI) of the experimental animals (Table 6) in $T_{0}, T_{1}$ and $T_{2}$ groups was $4.90 \pm 0.31,5.14 \pm 0.21$ and $5.32 \pm 0.30 \mathrm{~kg} / \mathrm{d}$, respectively and the same when expressed as $\mathrm{kg} / 100 \mathrm{~kg}$ body weight was $1.67 \pm 0.01,1.77 \pm 0.04$ and $1.81 \pm 0.06$ and in terms of $\mathrm{g} / \mathrm{kg} \mathrm{W}^{0.75}$ was recorded as $68.90 \pm 1.27,72.95 \pm 0.76$ and $74.66 \pm 1.82$, respectively. The DDMI of animals in $\mathrm{T}_{1}$ and $\mathrm{T}_{2}$ groups was significantly higher $(\mathrm{P}<0.05)$ as compared to $\mathrm{T}_{0}$ group. It is evident that inclusion of live yeast (Saccharomyces cerevisiae) in the ration had an influence on the digestible dry matter intake in terms of $\mathrm{kg} / \mathrm{day}, \mathrm{kg} / 100 \mathrm{~kg}$ body weight and metabolic body weight in the experimental animals.

\section{Average daily digestible organic matter intake:-}

The average daily digestible organic matter intake (DOMI) of the experimental animals in $T_{0}, T_{1}$ and $T_{2}$ groups was $3.44 \pm 0.15,4.11 \pm 0.17$ and $4.18 \pm 0.19 \mathrm{~kg} / \mathrm{d}$, respectively and the same when expressed as $\mathrm{kg} / 100 \mathrm{~kg}$ body weight was $1.21 \pm 0.04,1.42 \pm 0.05$ and $1.43 \pm 0.05$ and in terms of $\mathrm{g} / \mathrm{kg} \mathrm{W}^{0.75}$ was recorded as $48.66 \pm 1.78,58.38 \pm 1.05$ and 58.86 \pm 1.06 , respectively. The DOMI $\left(\mathrm{g} / \mathrm{kg} \mathrm{W}{ }^{0.75}\right)$ of animals fed $\mathrm{T}_{1}$ and $\mathrm{T}_{2}$ groups were significantly higher $(\mathrm{P}<0.05)$ as compared to $\mathrm{T}_{0}$ group. The intake of digestible organic matter of rations in terms of metabolic body weight was influenced by inclusion of live yeast (Saccharomyces cerevisiae) in the ration. 


\section{Digestion trial to study digestibility of nutrients:-}

\section{Digestibility of nutrients:-}

The digestibility coefficients of TMRs for DM, OM, CP, NFE, EE, CF, NDF, ADF, cellulose and hemi-cellulose have been depicted in Table 7.

Table 7:- Effect of YC supplementation on average digestibility coefficients (\%) of nutrients

\begin{tabular}{|l|c|c|c|}
\hline Digestibility coefficients (\%) & $\mathbf{T}_{\mathbf{0}}$ & $\mathbf{T}_{\mathbf{1}}$ & $\mathbf{T}_{\mathbf{2}}$ \\
\hline Dry matter digestibility (DMD) & $55.50^{\mathrm{a}} \pm 0.93$ & $59.73^{\mathrm{b}} \pm 0.79$ & $60.10^{\mathrm{b}} \pm 0.75$ \\
\hline Organic matter digestibility (OMD) & $57.65^{\mathrm{a}} \pm 1.40$ & $61.87^{\mathrm{b}} \pm 1.38$ & $61.30^{\mathrm{b}} \pm 0.38$ \\
\hline Crude protein digestibility (CPD) & $61.18^{\mathrm{a}} \pm 0.62$ & $68.08^{\mathrm{b}} \pm 0.84$ & $68.11^{\mathrm{b}} \pm 0.93$ \\
\hline Nitrogen free extract digestibility (NFED) & $57.23 \pm 0.83$ & $58.81 \pm 0.77$ & $58.20 \pm 0.53$ \\
\hline Ether extract digestibility (EED) & $65.76 \pm 2.27$ & $70.88 \pm 2.22$ & $68.61 \pm 1.03$ \\
\hline Crude fibre digestibility (CFD) & $53.20^{\mathrm{a}} \pm 0.65$ & $62.86^{\mathrm{b}} \pm 0.68$ & $63.58^{\mathrm{b}} \pm 0.81$ \\
\hline Neutral detergent fibre digestibility (NDFD) & $57.23^{\mathrm{a}} \pm 0.83$ & $59.90^{\mathrm{b}} \pm 0.74$ & $59.81^{\mathrm{b}} \pm 0.18$ \\
\hline Acid detergent fibre digestibility (ADFD) & $54.46^{\mathrm{a}} \pm 1.58$ & $58.47^{\mathrm{b}} \pm 0.76$ & $61.17^{\mathrm{b}} \pm 0.46$ \\
\hline Cellulose digestibility (CD) & $55.35^{\mathrm{a}} \pm 0.66$ & $61.25^{\mathrm{b}} \pm 0.73$ & $60.53^{\mathrm{b}} \pm 0.82$ \\
\hline Hemi-cellulose digestibility (HCD) & $57.65^{\mathrm{a}} \pm 0.87$ & $63.88^{\mathrm{b}} \pm 0.81$ & $63.03^{\mathrm{b}} \pm 0.94$ \\
\hline
\end{tabular}

${ }^{a, b}$ Means bearing different superscripts in a row differ significantly at $P<0.05$

\section{Dry matter digestibility (DMD):-}

The average DM digestibility coefficient (\%) of experimental animals in $\mathrm{T}_{0}, \mathrm{~T}_{1}$ and $\mathrm{T}_{2}$ groups was $55.73 \pm 0.50$, $59.73 \pm 0.79$ and $60.10 \pm 0.75$, respectively. The DMD of $\mathrm{T}_{1}$ and $\mathrm{T}_{2}$ group was significantly $(\mathrm{P}<0.05)$ higher than $\mathrm{T}_{0}$ group. Rao et al. (2001), Kumar and Reddy (2004) and Mahender et al. (2006) reported higher DM digestibility on feeding yeast culture to animals in experimental group. However, Mir and Mir (1994) did not observe any difference in DM digestibility on account of supplementing probiotics. Thus, inclusion of live yeast (Saccharomyces cerevisiae) in the ration had a positive influence on the DM digestibility of nutrients in the experimental animals.

\section{Organic matter digestibility (OMD):-}

The average OM digestibility coefficient $(\%)$ of experimental animals under $\mathrm{T}_{0}, \mathrm{~T}_{1}$ and $\mathrm{T}_{2}$ groups was $57.65 \pm 1.40$, $61.87 \pm 1.38$ and $61.30 \pm 0.38$, respectively. The $\mathrm{OMD}$ of $\mathrm{T}_{1}$ and $\mathrm{T}_{2}$ groups was significantly $(\mathrm{P}<0.01)$ higher than $\mathrm{T}_{0}$ group. Mahender et al. (2006) and Pandey and Agrawal (2001b) also reported higher OM digestibility on feeding yeast culture to experimental animals. Yeast supplementation increased rumen $\mathrm{pH}$, VFA concentration, and OM digestibility and tended to decrease rumen lactate concentration.

\section{Crude protein digestibility (CPD):-}

The average CP digestibility coefficient (\%) of experimental animals under $\mathrm{T}_{0}, \mathrm{~T}_{1}$ and $\mathrm{T}_{2}$ groups was $61.18 \pm 0.62$, $68.08 \pm 0.84$ and $68.11 \pm 0.93$, respectively. The CPD of animals under $T_{1}$ and $T_{2}$ groups were significantly higher $(\mathrm{P}<0.01)$ as compared to $\mathrm{T}_{0}$ group. Pandey and Agrawal (2001b), Kumar and Reddy (2004) and Mahender et al. (2006) reported higher CP digestibility on feeding yeast culture to experimental animals. However, Rao et al. (2001) reported significantly lower $\mathrm{CP}$ digestibility $(\mathrm{P}<0.01)$ in complete rations of animals supplemented with Saccharomyces cerevisiae.

\section{Nitrogen free extract digestibility (NFED):-}

The average NFE digestibility coefficient (\%) of experimental animals under $\mathrm{T}_{0}, \mathrm{~T}_{1}$ and $\mathrm{T}_{2}$ groups was $57.23 \pm 0.83$, $58.81 \pm 0.77$ and $58.20 \pm 0.53$, respectively. The treatment groups did not differ statistically $(\mathrm{P}<0.05)$ from each other. These findings are corroborated by the reports of Kumar and Reddy (2004) and Chaudhary et al. (2008). However, Mahender et al. (2006) observed significantly $(\mathrm{P}<0.05)$ higher NFE digestibility in animals reared on complete diet with yeast culture@ $0.1 \%$.

\section{Ether extract digestibility (EED):-}

The average EE digestibility coefficient $(\%)$ in $\mathrm{T}_{0}, \mathrm{~T}_{1}$ and $\mathrm{T}_{2}$ groups was $65.76 \pm 2.27,70.88 \pm 2.22$ and $68.61 \pm 1.03$, respectively. With respect to the digestibility coefficient of EE, the dietary treatments did not differ. Other workers viz. Pandey and Agrawal (2001b), Mahender et al. (2006) and Hossain et al. (2012) did not find any influence of inclusion of Saccharomyces cerevisiae to experimental animals on different feeding regime. However, Chaudhary et 
al. (2008) and Kumar and Reddy (2004) observed improvement in EE digestibility on account of feeding yeast culture.

\section{Crude fibre digestibility (CFD):-}

The average CF digestibility coefficient (\%) of experimental animals in $\mathrm{T}_{0}, \mathrm{~T}_{1}$ and $\mathrm{T}_{2}$ groups was 53.20 \pm 0.65 , $62.86 \pm 0.68$ and $63.58 \pm 0.81$, respectively. The CFD of $\mathrm{T}_{1}$ and $\mathrm{T}_{2}$ groups was significantly $(\mathrm{P}<0.01)$ higher than $\mathrm{T}_{0}$ group. Kumar and Reddy (2004), Mahender et al. (2006), Francia et al. (2008) and Hossain et al. (2012) also observed improvement in CFD when the animals were supplemented with Saccharomyces cerevisiae. Similarly, Guedes et al. (2008) observed improved fibre digestibility with supplemental live yeast on low quality versus highquality corn silage based ration.

\section{Neutral detergent fibre digestibility (NDFD):-}

The average NDF digestibility coefficient $(\%)$ of experimental animals in $\mathrm{T}_{0}, \mathrm{~T}_{1}$ and $\mathrm{T}_{2}$ groups was 57.23 \pm 0.83 , $59.90 \pm 0.74$ and 59.81 \pm 0.18 , respectively. The NDFD of $\mathrm{T}_{1}$ and $\mathrm{T}_{2}$ groups was significantly $(\mathrm{P}<0.01)$ higher than $\mathrm{T}_{0}$ group. Kumar and Reddy (2004), Mahender et al. (2006) and Francia et al. (2008) also observed improvement in NDFD when the growing animals were supplemented with Saccharomyces cerevisiae. Bitencourt et al. (2008) found increased total tract NDF digestion by $11.3 \%$, from $43.2 \%$ to $48.1 \%$, with the addition of live yeast to the diet.

\section{Acid detergent fibre digestibility (ADFD):-}

The average ADF digestibility coefficient $(\%)$ of experimental animals in $\mathrm{T}_{0}, \mathrm{~T}_{1}$ and $\mathrm{T}_{2}$ groups was 54.46 \pm 1.58 , $58.47 \pm 0.76$ and $61.17 \pm 0.46$, respectively. The ADFD of $\mathrm{T}_{1}$ and $\mathrm{T}_{2}$ groups was significantly $(\mathrm{P}<0.01)$ higher than $\mathrm{T}_{0}$ group. Kumar and Reddy (2004), Mahender et al. (2006) and Francia et al. (2008) also observed improvement in ADFD when the growing animals were supplemented with Saccharomyces cerevisiae.

\section{Cellulose digestibility (CD):-}

The average cellulose digestibility coefficient $(\%)$ of experimental animals in $\mathrm{T}_{0}, \mathrm{~T}_{1}$ and $\mathrm{T}_{2}$ groups was 55.35 \pm 0.66 , $61.25 \pm 0.73$ and $60.53 \pm 0.82$, respectively. The $\mathrm{CD}$ of $\mathrm{T}_{1}$ and $\mathrm{T}_{2}$ groups was significantly $(\mathrm{P}<0.01)$ higher than $\mathrm{T}_{0}$ group. Kumar and Reddy (2004), Mahender et al. (2006) and Francia et al (2008) also observed improvement in CD when the animals were supplemented with Saccharomyces cerevisiae.

\section{Hemi-cellulose digestibility (HCD):-}

The average hemi-cellulose digestibility coefficient $(\%)$ of experimental animals in $\mathrm{T}_{0}, \mathrm{~T}_{1}$ and $\mathrm{T}_{2}$ groups was $57.65 \pm 0.87,63.88 \pm 0.81$ and $63.03 \pm 0.94$, respectively. The $\mathrm{HCD}$ of $\mathrm{T}_{1}$ and $\mathrm{T}_{2}$ groups was significantly $(\mathrm{P}<0.01)$ higher than $\mathrm{T}_{0}$ group. Kumar and Reddy (2004), Mahender et al. (2006) and Francia et al. (2008) also observed improvement in HCD when the animals were supplemented with Saccharomyces cerevisiae.

\section{Conclusion:-}

From the present study, it could be concluded that supplementation of yeast culture (Saccharomyces cerevisiae) strains YC-1026 and YC-1077@ 15 and $1.5 \mathrm{~g} / \mathrm{animal} /$ day, respectively, in the ration of Kankrej cows was found to be beneficial in improving the rumen fermentation and digestibility of nutrients without affecting bio-chemical profile.

\section{Acknowledgements:-}

The authors express their thanks and gratitude to Professors of Animal Nutrition Research Station and management of Anand Agricultural University, Anand, for their valuable support towards the execution and completion of this study. Constructive inputs and assistance provided by Dr M R Garg, General Manager, National Dairy Development Board, Anand, is gratefully acknowledged. Authors are also grateful to Dr CB Pandey, Lallemand Animal Nutrition for providing yeast culture for this research. 


\section{References:-}

1. Adams A L, Harris Jr B, Van Horn H H and Wilcox C J 1995 Effects of varying forage types on milk production responses to whole cottonseed, tallow and yeast. Journal of Dairy Science 78:573-581

2. Allison M J, Robinson I M, Bucklin J A and Booth G D 1979 Comparison of bacterial populations of the caecum and colon based on enumeration with specific energy sources. Applied Environmental Microbiology 37:1142

3. Alshaikh M A, Alsiadi M Y, Zahran S M, Mogawer H H and Aalshowime T A 2002 Effect of feeding yeast culture from different sources on the performances of lactating cows in Saudi Arabia. Asian-Australasian Journal of Animal Sciences 15(3):352-356 https://www.researchgate.net/publication/ 228755803_Effect_of_Feeding_Yeast_Culture_from_Different_Sources_on_the_Performance_of_Lactating_H olstein_Cows_in_Saudi_Arabia

4. Ametaj B N, Emmanuel D G V, Zebeli Q and Dunn S M 2009 Feeding high proportions of barley grain in a total mixed ration perturbs diurnal patterns of plasma metabolites in lactating dairy cows. Journal of Dairy Science 92:1084-1091 http://www.ncbi.nlm.nih.gov/pubmed/19233801

5. AOAC 1995 Official Methods of Analysis $\left(15^{\text {th }}\right.$ ed.). Arlington, VA: Association of Official Analytical Chemists

6. Arambel M J and Kent B A 1990 Effect of yeast culture on nutrient digestibility and milk yield response in early to mid lactation dairy cows. Journal of Dairy Science 73:1560-1563 http://www.ncbi.nlm.nih.gov/pubmed/2200812

7. Bagheri M, Ghorbani G R, Rahmani H R, Khorvash M, Nili N and Südekum K H 2009 Effect of live yeast and mannan-oligosaccharides on performance of early-lactation Holstein dairy cows. Asian-Australasian Journal of Animal Sciences 22:812-818 http://ajas.info/journal/view.php?number=22098

8. Barnett A J G and Reid R L 1957 Studies on production of volatile fatty acids from grass by rumen liquor in artificial rumen. I. Volatile fatty acid production from fresh grass. Journal of Agricultural Science 48:315-321 http://www.cabdirect.org/abstracts/19571403500.html;jsessionid=84D6EC4CF22CBF22D10E33AB2C974E0F

9. Bitencourt L L, Pereira M N, de Oliveira B M L, Silva J R M, Dias Jr G S, Lopes F, de Melo R C M and Siecola Jr S 2008 Response of lactating cows to the supplementation with live yeast. Journal of Dairy Science 91(Suppl. 1):264 (Abstr.)

10. Boyd J W 1983 The mechanism relating to increase in plasma enzymes and iso-enzymes in diseases of animals. Veterinary Clinical Pathology 12:9-24

11. Bryant M P, Small N, Bouma C and Robinson I 1958 Studies on the composition of the ruminal flora and fauna of young calves. Journal of Dairy Science 41:1747 http://www.journalofdairyscience.org/article/S00220302(58)91160-3/abstract

12. Bryant M P and Robinson I M 1963 Apparent incorporation of ammonia and amino acid carbon during growth of selected species of ruminal bacteria. Journal of Dairy Science 46: 150 http://www.journalofdairyscience.org/article/S0022-0302(63)88991-2/abstract

13. Callaway E S and Martin S A 1997 Effect of Saccharomyces cerevisiae culture on ruminal bacteria that utilize lactate and digest cellulose. Journal of Dairy Science 80:2035-2044 http://www.ncbi.nlm.nih.gov/pubmed/9313145

14. Chaucheyras-Durand F and Fonty G 2001 Establishment of cellulolytic bacteria and development of fermentative activities in the rumen on gnotobiotically-reared lambs receiving the microbial additive Saccharomyces cerevisiae CNCM I-1077. Reproduction Nutrition Development 41:57-68 https://hal.inria.fr/file/index/docid/900420/filename/hal-00900420.pdf

15. Chaudhary L C, Sahoo A, Agarwal N, Kamra D N and Pathak N N 2008 Effect of direct fed microbials on nutrient utilization, rumen fermentation, immune and growth response in crossbred cattle calves. Indian Journal of Animal Sciences 78:515-521 http://agris.fao.org/agris-search/search.do?recordID=IN2010000619

16. Cornelius C E 1980 Liver function In: Kaneko J J (eds). Clinical Biochemistry of Domestic Animals. $3^{\text {th }}$ ed, Academic press Inc. New York, USA, pp. 225-294 http://www.sciencedirect.com/science/book/9780123704917

17. Dawson K A and Newman K E 1987 Effects of yeast culture supplements on the growth and activities of rumen bacteria in continuous culture. Journal of Animal Science 65(Suppl. 1):452(Abstr.)

18. Dawson K A and Tricarico J 2002 The evolution of yeast cultures-20 years of research. Page No. 26-43, in Navigating from Niche Markets to Mainstream: Proceedings of Alltech's European, Middle Eastern and African Lecture Tour

19. Dawson K A, Newman K E and Boling J A 1990 Effect of microbial supplement containing yeast and lactobacilli on roughage fed ruminal microbial activities. Journal of Animal Science 68:3392-3398 
https://www.researchgate.net/publication/21031883_Effect_of_microbial_supplements_containing_yeast_and_1 actobacilli_on_roughage-fed_ruminal_microbial_activities

20. Desnoyers M, Giger-Reverdin S, Bertin G, Duvaux-Ponter C and Sauvant D 2009 Meta-analysis of the influence of Saccharomyces cerevisiae supplementation on ruminal parameters and milk production of ruminants. Journal of Dairy Science92:1620-1632 http://www.ncbi.nlm.nih.gov/pubmed/19307644

21. Erasmus L J, Botha P M and Kistner A 1992 Effect of yeast culture supplement on production, rumen fermentation, and duodenal nitrogen flow in dairy cows. Journal of Dairy Science 75:3056-3065 http://www.ncbi.nlm.nih.gov/pubmed/1460136

22. Evans A J 1988 Hepatobiliary damage and dis-function: A critical review. In: Blackmore A J (Eds), Animal Clinical Biochemistry, Cambridge

23. Francia A D, Masucci F, Rosa G De, Varricchio M L and Proto V 2008 Effects of Aspergillus oryzae extract and a Saccharomyces cerevisiae fermentation product on intake, body weight gain and digestibility in buffalo calves. Animal Feed Science and Technology 140:67-77 http://www.sciencedirect.com/science/article/pii/S0377840107000703

24. Garg M R, Sherasia P L, Bhanderi B M, Phondba B T, Shelke S K and Makkar H P S 2012 Effects of feeding nutritionally balanced rations on animal productivity, feed conversion efficiency, feed nitrogen use efficiency, rumen microbial protein supply, parasitic load, immunity and enteric methane emissions of milking animals under field conditions. Animal Feed Science and Technology 179:24-35 http://www.sciencedirect.com/science/article/pii/S0377840112003902

25. Grieve D G 1979 Feed intake and growth of cattle fed liquid brewer's yeast. Journal of Animal Science 589:8994 http://agris.fao.org/agris-search/search.do?recordID=CA19790465416

26. Guedes C M, Goncalves D, Rodrigues M A M and Dias-da-Silva A 2008 Effect of yeast Saccharomyces cerevisiae on ruminal fermentation and fibre degradation of maize silage in cows. Animal Feed Science and Technology 145:27-40 http://www.sciencedirect.com/science/article/pii/S037784010700286

27. Harrison G A, Hemken R W, Dawson K A, Harmon R J and Barker K B 1988 Influence of addition of yeast culture supplement to diets of lactating cows on ruminal fermentation and microbial populations. Journal of Dairy Science 71:2967-2975 http://www.ncbi.nlm.nih.gov/pubmed/3230186

28. Hossain S A, Parnerkar S, Haque N, Gupta R S, Kumar D and Tyagi A K 2012 Influence of dietary supplementation of live yeast (Saccharomyces cerevisiae) on nutrient utilization, ruminal and biochemical profiles of Kankrej calves. International Journal of Applied Animal Sciences 1(1):30-38 https://www.researchgate.net/publication/265651109_Influence_of_dietary_supplementation_of_live_yeast_Sa ccharomyces_cerevisiae_on_nutrient_utilization_ruminal_and_biochemical_profiles_of_Kankrej_calves

29. Hucko B, Bampidis V A, Kodes A, Christodoulou V, Mudrik Z, Poláková K and Plachy V 2009 Rumen fermentation characteristics in pre-weaning calves receiving yeast culture supplements. Czech Journal of Animal Science 54(10):435-442 http://www.agriculturejournals.cz/publicFiles/11488.pdf

30. Isik M, Ekimler F, Ozen N and Firat M Z 2004 Effect of using probiotics on growth performance and health of dairy calves. Turkish Journal of Veterinary and Animal Sciences 28:63-69 http://dergipark.ulakbim.gov.tr/tbtkveterinary/article/view/5000030599

31. Jain N C 1993 Essentials of Veterinary Haematology. Lea and Febger, Philadelphia, USA http://www.amazon.com/Essentials-Veterinary-Hematology-Nemi-Jain/dp/081211437X

32. Joshi N R and Phillips R W 1953 Zebu cattle of India and Pakistan. FAO Agriculture Studies no. 19, publication by FAO, Rome, pp. 256

33. Kaneko J J, Harvey J W and Bruss M L 1997 Clinical Biochemistry of Domestic Animals. $5^{\text {th }}$ Ed, Academic press, San Diego, USA http://www.sciencedirect.com/science/book/9780123704917

34. Kobayashi T, Oda S, Takenaka A and Itabashi H 1995 Effects of yeast culture supplement on milk protein yield, ruminal fermentation and blood components in early to mid-lactation dairy cows. Bulletin of National Institute Animal Industry 55:13-20 http://agris.fao.org/agris-search/search.do?recordID=JP9602549

35. Koul V, Kumar U, Sareen V K and Singh S 1998 Mode of action of yeast culture (Yea Sacc-1026) for stimulation of rumen fermentation in buffalo calves. Journal of the Science of Food and Agriculture 77:407-413 https://www.researchgate.net/publication/227949253_Mode_of_action_of_yeast_culture_YEA-SACC_1026_ for_stimulation_of_rumen_fermentation_in_buffalo_calves

36. Kramer J W 1989 Clinical Biochemistry of Domestic Animals. $4^{\text {th }}$ ed. (Ed. J.J. Kaneko), Academic Press, San Diego, California, USA

37. Kumar M K and Reddy G V K 2004 Effect of supplementation of yeast culture (Saccharomyces cerevisiae) to roughage based ration in crossbred heifers. Indian Journal of Animal Nutrition 21:36-39 
38. Kumar U, Sareen V K and Singh S 1997 Effect of yeast culture supplement on ruminal microbial population and metabolism in the buffalo calves fed a high roughage diet. Journal of the Science of Food and Agriculture 73:231-236 http://onlinelibrary.wiley.com/doi/10.1002/(SICI)1097-0010(199702)73:2\%3C231::AIDJSFA710\%3E3.0.CO;2-D/abstract

39. Laborde J M 2008 Effects of probiotics and yeast culture on rumen development and growth of dairy calves. Thesis submitted to the Graduate Faculty of the Louisiana State University and Agricultural and Mechanical College, USA

40. Lane G T, Noller C H, Clendrander V P, Cummings K R and Harzington R B 1968 Apparatus for obtaining rumino-reticular samples and the effect of sampling location on $\mathrm{pH}$ and volatile fatty acids. Journal of Dairy Science 51:114-123 http://www.ncbi.nlm.nih.gov/pubmed/5640013

41. Lascano G J and Heinrichs A J 2009 Rumen fermentation pattern of dairy heifers fed restricted amounts of low, medium, and high concentrate diets without and with yeast culture. Livestock Science 124:48-57 http://www.sciencedirect.com/science/article/pii/S1871141308004034

42. Lesmeister K E, Heinrichs A J and Gabler M T 2004 Effect of supplemental yeast (Saccharomyces cerevisiae) culture on rumen development, growth characteristics and blood parameters in neonatal dairy calves. Journal of Dairy Science 87:1832-1839 http://www.ncbi.nlm.nih.gov/pubmed/15453499

43. Lila Z A, Mohammed N, Yasui T, Kurokawa Y, Kanda S and Itabashi H 2004 Effects of a twin strain of Saccharomyces cerevisiae live cells on mixed ruminal microorganism fermentation in vitro. Journal of Animal Science 82:1847-1854 http://www.ncbi.nlm.nih.gov/pubmed/15217013

44. Mahender M V, Prasad LK and Reddy G V N 2006 Effect of yeast culture on growth and nutrient utilization in Nellore lambs. Indian Journal of Animal Nutrition 23:10-13 http://www.indianjournals.com/ ijor.aspx?target $=$ ijor:ijan \& volume $=23 \&$ issue $=1 \&$ article $=003$

45. Malik R and Sharma D D 1998 In vitro evaluation of different probiotics as feed supplement. Indian Journal of Dairy Science 51:357-362

46. Mason I L 1996 A world dictionary of livestock breeds, types and varieties. Fourth Edition, CAB International, pp. 273

47. Mathison G W and Milligan L P 1971 Nitrogen metabolism in sheep. British Journal of Nutrition 25:351

48. Mir Z and Mir P S 1994 Effect of the addition of live yeast (Saccharomyces cerevisiae) on growth and carcass quality of steers fed high-forage or high-grain diets and on feed digestibility and in situ degradability. Journal of Animal Science 72:537-545 http://www.ncbi.nlm.nih.gov/pubmed/8181967

49. Mosoni P, Chaucheyras-Durand F, Bera-Maillet C and Forano E 2007. Quantification by real-time PCR of cellulolytic bacteria in the rumen of sheep after supplementation of a forage diet with readily fermentable carbohydrates: Effect of a yeast additive. Journal of Applied Microbiology 103:2676-2685 http://www.chemistryexplained.com/index.html

50. Mutsvangwa T 1992 The effects of the inclusion of a yeast culture supplement in the diet on milk yield and milk composition of dairy cows and on digestion and patterns of ruminal fermentation in steers. Zimbabwe Journal of Agricultural Research 30:21-31

51. NRC 2001 Nutrient Requirements of Dairy Cattle. $7^{\text {th }}$ Rev. ed. National Academy Press, Washington, DC http://profsite.um.ac.ir/ kalidari/software/NRC/HELP/NRC\%202001.pdf

52. Ondarza M B, Sniffen C J, Dussert L, Chevaux E and Sullivan J 2011 Live yeast aids rumen function, milk yield. $\quad$ Feedstuffs $\quad 83(4): 1-3 \quad \mathrm{http} / / /$ mailing.lallemandanimalnutrition.com/110208/Feedstuffs 012411deOndarza.pdf

53. Panda AK, Singh R and Pathak N N 1995 Effect of dietary inclusion of Saccharomyces cerevisiae on growth performance of crossbred calves. Journal of Applied Animal Research 7:195-200 http://www.tandfonline.com/doi/pdf/10.1080/09712119.1995.9706071

54. Panda A K, Singh R and Pathak N N 1999 Effect of dietary inclusion of Saccharomyces cerevisiae on rumen fermentation in crossbred calves. Indian Journal of Animal Nutrition 16:291-294

55. Pandey P and Agrawal I S 2001a Influence of dietary supplementation of antibiotic and probiotic on rumen fermentation in crossbred bullocks. Indian Journal of Animal Nutrition 18: 19-22 http://www.indianjournals.com/ijor.aspx?target=ijor:ijan\&volume=18\&issue $=1 \&$ article $=003$

56. Pandey P and Agrawal I S 2001b Nutrient utilization and growth response in crossbred calves fed antibiotic and probiotic supplemented diets. Indian Journal of Animal Nutrition 18: 15-18 http://www.indianjournals.com/ijor.aspx?target=ijor:ijan\&volume=18\&issue $=1 \&$ article $=003$

57. Pearson R M and Smith J A B 1943 The utilization of urea in the bovine rumen. I. Methods of analysis of the rumen ingesta and preliminary experiments in vitro. Biochemical Journal 37:141-148 http://www.indianjournals.com/ijor.aspx?target=ijor:ijan\&volume=18\&issue=1\&article=004 
58. Pensent P J N 1983 The diagnosis of diseases of bovine liver- a clinician's view. Bovine Practice 18:165-188

59. Phondba B T, Kank V D, Patil M B, Gadegaonkar G M, Jagadale S D and Bade R N 2009 Effect of feeding probiotic feed supplement on yield and composition of milk in crossbred cows. Animal Nutrition and Feed Technology 9:245-252 http://www.indianjournals.com/ijor.aspx?target=ijor:anft\&volume=9\&issue=2\&article $=015$

60. Pinos-Rodriguez J M, Robinson P H, Ortega M E, Berry S L, Mendoza G and Barcena R 2008 Performance and rumen fermentation of dairy calves supplemented with Saccharomyces cerevisiae-1077 or Saccharomyces boulardii-1079. Animal Feed Science and Technology 140:223-232 http://www.sciencedirect.com/ science/article/pii/S0377840107003264

61. Piva G, Belladonna S, Fusconi G and Siebaldi F 1993 Effects of yeast on dairy cows performance, ruminal fermentation, blood components, and milk manufacturing properties. Journal of Dairy Science 76:2717-2722 http://www.ncbi.nlm.nih.gov/pubmed/8227674

62. Putnam D E, Schwab C G, Socha M T, Whitehouse N L, Kierstead N A and Garthwaite B D 1997 Effect of yeast culture in the diets of early lactation dairy cows on ruminal fermentation and passage of nitrogen fractions and amino acids to the small intestine. Journal of Dairy Science 80:374-384 http://www.ncbi.nlm.nih.gov/pubmed/9058280

63. Quigley J D, Wallis L B, Dowlen H H and Heitmann R N 2007 Sodium bicarbonate and yeast culture effects on ruminal fermentation, growth and intake in dairy calves. Journal of Animal Science 85:1264-1273 http://www.ncbi.nlm.nih.gov/pubmed/1335462

64. Rao T N, Rao Z P and Rama Prasad J 2001 Supplementation of probiotics on growth performance in sheep. Indian Journal of Animal Nutrition 20:224-226

65. Rao T N, Rao Z P, Rama J P and Prasad P E 2003 Effect of probiotic supplementation to complete rations on the nutrient digestibility and rumen environment in sheep. Indian Journal of Animal Nutrition 18:133-137 http://www.indianjournals.com/ijor.aspx?target=ijor:ijan \&volume=18\&issue=2\&article $=005$

66. Reddy G V N and Bhima B 2003 Effect of yeast culture based diet on growth and nutrient utilization in twelve Deoni bull calves. Indian Journal of Animal Nutrition 20:101-104 https://www.researchgate.net/publication/259872865_Effect_of_yeast_culture_based_diet_on_growth_and_nutr ient_utilization_in_deoni_bull_calves

67. Robinson P H and Garrett J E 1999 Effect of yeast culture (Saccharomyces cerevisiae) on adaption of cows to postpartum diets and on lactation performance. Journal of Animal Science 77:988-999 http://www.ncbi.nlm.nih.gov/pubmed/10328367

68. Sakine Y, Suzan Y, Pınar C, Arif O G, Cemalettin B and Önder E 2011 The nutritive value of live yeast culture (Saccharomyces cerevisiae) and its effect on milk yield, milk composition and some blood parameters of dairy cows. Asian-Australian Journal of Animal Sciences 24(10):1377-1385 http://www.ajas.info/journal/view.php?number=22595

69. Schingoethe D J, Linke K N, Kalscheur K F, Hippen A R, Rennich D R and Yoon I 2004 Feed efficiency of mid lactating dairy cows fed yeast culture during summer. Journal of Dairy Science 87:4178-4181 http://www.ncbi.nlm.nih.gov/pubmed/15545380

70. Singh R, Chaudhary L C, Kamra D N and Pathak N N 1998 Effect of dietary supplementation with yeast cell suspension on nutrient utilization and growth response in crossbred calves. Asian-Australian Journal of Animal Sciences 11: 329-336 http://www.ajas.info/journal/view.php?number=19280

71. Snedecor G W and Cochran W G 1994 Statistical Methods. $8^{\text {th }}$ ed., Oxford and IBH Publishing Co. Pvt. Ltd., New Delhi, India

72. Soder K J and Holden L A 1999 Dry matter intake and milk yield and composition of cows fed yeast prepartum and postpartum. Journal of Dairy Science 82:605-610 http://www.ncbi.nlm.nih.gov/pubmed/10194680

73. Stella A V, Paratte R, Valnegri L, Cigalino G, Soncini G, Chevaux E, Dell'Orto V and Savoini G 2007 Effect of administration of live Saccharomyces cerevisiae on milk production, milk composition, blood metabolites and faecal flora in early lactating dairy goats. Small Ruminant Research 67:7-13 http://www.sciencedirect.com/science/article/pii/S0921448805003585

74. Thrune M, Bach A, Ruiz-Moreno M, Stern M D and Linn J G 2009 Effects of Saccharomyces cerevisiae on ruminal $\mathrm{pH}$ and microbial fermentation in dairy cows yeast supplementation on rumen fermentation. Livestock Science 124: 261-265 http://www.livestockscience.com/article/S1871-1413(09)00058-4/abstract

75. Tripathi M K, Karim S A, Chaturvedi O H and Verma D L 2008 Effect of different liquid cultures of live yeast strains on performance, ruminal fermentation and microbial protein synthesis in lambs. Journal of Animal Physiology and Animal Nutrition 92: 631-639 
76. Van Soest P J, Robertson J B and Lewis B A 1991 Methods of dietary fibre, neutral detergent fibre and nonstarch polysaccharides in relation to animal nutrition. Journal of Dairy Science 74:3583-3597 http://www.ncbi.nlm.nih.gov/pubmed/1660498

77. Weidmeier R D, Arambel M J and Walters J L 1987 Effect of yeast culture and Aspergillus oryzae fermentation extract on ruminal characteristics and nutrient digestibility. Journal of Dairy Science 70: 2063-2071 http://www.journalofdairyscience.org/article/S0022-0302(87)80254-0/abstract

78. Williams P E V 1989 Understanding the biochemical mode of action of yeast culture. Page No. 79-101, in Proceedings No.119 on "Animal Feeds Biochemical Additives", University of Sydney, Australia

79. Williams P E V and Newbold C J 1990 Rumen probiosis: The effects of novel microorganisms on rumen fermentation and ruminant productivity. Page No. 211-227, In: "Recent Advances in Animal Nutrition", W Haresing and D J A Cole (Editor), Butterworths, London, UK

80. Williams P E V, Tait C A G, Innes G M and Newbold C J 1991 Effects of the inclusion of yeast culture in the diet of dairy cows on milk yield and forage degradation and fermentation patterns in the rumen of steers. Journal of Animal Science 69: 3016-3026 http://www.ncbi.nlm.nih.gov/pubmed/1885411

81. Wohlt J E, Finkelstein A D and Ghung C H 1991 Yeast culture to improve intake, nutrient digestibility and performance by dairy cattle during early lactation. Journal of Dairy Science 74:1395-1400 http://www.ncbi.nlm.nih.gov/pubmed/1650383

82. Wohlt J E, Corcione T T and Zajac P K 1998 Effect of yeast on feed intake and performance of cows fed diets based on corn silage during early lactation. Journal of Dairy Science 81:1345-1352 http://www.ncbi.nlm.nih.gov/pubmed/9621237

83. Yadav M S, Sengupta B P, Yadav R S and Singh A 1996 Effect of feeding yeast culture with bypass protein on growth, feed efficiency and ruminal profile in Murrah buffalo calves and heifers. Indian Journal of Animal Production and Management 12:170-173

84. Zhang Y L, Cheng Q F, Cao Y X, Wang Y H, Zhang Z S, Wu Y Q and Zhou Y Y 2000 Effects of yeast (Saccharomyces cerevisiae) on milk production and composition in Holstein dairy cows. Cited from: China Dairy Cattle 5:20-22 